\title{
Impact of transient temperature disturbance on the oxidative stress indices and glucose levels of juvenile Koi carps (Cyprinus carpio var koi)
}

\author{
Bela Zutshi, Aradhana Singh and Proteek Dasgupta * (1)
}

\begin{abstract}
Background: The present study reports the changes in the redox state and glucose activity in gills and muscles of Koi carps, exposed to a short duration of acute thermal stress. The variation in levels of lipid peroxidation (LPO) and glutathione (GSH), catalase (CAT) and glutathione-S-transferase (GST) activity, in addition to glucose levels, were analysed after exposing the fishes to $15^{\circ} \mathrm{C}$ (low), $25^{\circ} \mathrm{C}$ (control) and $35^{\circ} \mathrm{C}$ (high) for a duration of 3 and $6 \mathrm{~h}$. The upper and lower temperatures regimes were decided by the Critical Thermal Limit ( $C T_{\text {MAX }}$ and $\left.C T_{\text {MIN }}\right)$.

Results: The CAT activity was high in both the tissues at $35^{\circ} \mathrm{C}$ within $3 \mathrm{~h}$, while LPO activity decreased throughout the study when compared with the control group indicating immoderate cellular disturbance and surplus oxidative stress. At $15^{\circ} \mathrm{C}(3 \mathrm{~h})$, tissues reported more glucose compared with the upper thermal slab. GSH increased in both the tissues at $15^{\circ} \mathrm{C}$ compared with the control for 3 and $6 \mathrm{~h}$. GST activity, however, flourished at $35^{\circ} \mathrm{C}$ in muscles and gills for the 3-h regime.
\end{abstract}

Conclusion: The current study demonstrated disturbing impacts of temperature on the survivability of the Koi carps in a domesticated environment.

Keywords: Transient temperature, Oxidative stress, Glucose, Koi carps, Juveniles, Gills, Muscles

\section{Background}

Temperature is an important physiological regulator and primarily affects the body metabolism of aquatic organisms. Temperature disruption might affect a variety of activities ranging from lifestyle (Freitas et al., 2017), behaviour and swimming patterns (Campos, Val, \& Almeida-Val, 2018) to breeding and reproduction (Madeira, Vinagre, \& Diniz 2016a), predator-prey dynamics (Allan, Paolo, Munday, \& McCormick, 2015) and most importantly, longevity (Madeira, Madeira, Diniz, Cabral, \& Vinagre 2016b; Hsu \& Chiu, 2009; Dong, Dong, \& Ji, 2008). Acute temperature level has been closely associated with the generation of reactive oxygen/nitrogen species or the free radicals through mitochondria (Lushchak, 2016), thereby inducing oxidative

\footnotetext{
* Correspondence: proteek.dasgupta@gmail.com

Department of Zoology, Aquaculture Laboratory, Bangalore University, Bengaluru, Karnataka 560056, India
}

stress (Abele \& Puntarulo, 2004) and fishes are no exception to the same.

Lipid peroxidation products are among the best biomarkers for monitoring and analysing the cellular damage due to the generation of free radicals in aquatic organisms. This is substantiated by the fact that the fishes have high quantity polyunsaturated fatty acid residues that form an excellent substrate for the oxidation of fatty acids (Lushchak, 2011). The architecture of lipid peroxides is very balanced at normal physiological temperatures; however, they are prone to lose their stability once they are subjected to altered levels outside the ambient range (Gutteridge, 1995).

Superoxide radical $\left(\mathrm{O}_{2}{ }^{--}\right)$is reduced to hydrogen peroxide $\left(\mathrm{H}_{2} \mathrm{O}_{2}\right)$ and water through the first line of the antioxidant enzymes, the superoxide dismutase. Further, $\mathrm{H}_{2} \mathrm{O}_{2}$ is converted into water and oxygen by catalase (Di Giulio, Washburn, Wenning, Winston, \& Jewell, 1989; 
Lushchak, 2016). In case, catalase is not able to comprehend the reaction then, $\mathrm{H}_{2} \mathrm{O}_{2}$ eventually converts to highly reactive hydroxyl radical $\left(\mathrm{OH}^{*}\right)$ by the Fenton reaction. Any minute change in the metabolic balance due to stress might disrupt the enzymatic action of catalase.

The glutathione family of non-enzymatic antioxidants works on similar lines of catalase. Through, the multireactional approach, both GST and GSH along with other members remove $\mathrm{H}_{2} \mathrm{O}_{2}$ and are largely instrumental in quenching free radicals (Di Giulio et al., 1989), thereby alleviating oxidative stress. A $5{ }^{\circ} \mathrm{C}$ temperature variance in fishes might elevate the glutathione level and it would become more oxidised, thereby harmonizing the intracellular redox system (Kaur, Atif, Ali, Rehman, \& Raisuddin, 2005; Lushchak \& Bagnyukova, 2006; Parihar \& Dubey, 1995). Glucose, as a stress indicator has majorly been associated with a variety of stress factors (Kumar, Krishnani, \& Singh, 2018; Wells \& Pankhurst, 1999). Glycogenolysis and glucogenesis pathways elevate the production of glucose, which in mutual terms facilitates the cortisol level to counter the stressful conditions (Helly Jr., 1976).

Ornamental fish industry is a rapidly growing innovative economic venture and a major source of global livelihood. Cyprinus carpio var koi, an ornamental strain of the common carp is popular for its aesthetic values and coloration among aquarists. It is an endemic species of Japan, however, grown worldwide (Mabuchi, Seno, Suzuki, \& Nishida, 2005; Tripathi, Latimer, Lewis, \& Burnley, 2003). Like any ornamental fish, oxidative stress and associated survivability will undoubtedly influence the commercial importance of Koi carps in any habitat as there is no "zero stress" environment. Koi carps, known for displaying flashy colours has also been a model organism for the study of pigmentation pathways. Therefore, the present study was conducted to assess the role of temperature as a stress factor and evaluate the response through the quantification of glucose and antioxidant enzymes.

\section{Materials and methods}

\section{Fish acclimatisation}

Healthy juvenile Koi carps $(5.00 \pm 0.34 \mathrm{~g})$ were procured from Ornamental Fish Research Centre, Bengaluru, Karnataka. The fishes were acclimatised to laboratory condition for 14 days in $30 \mathrm{~L}$ glass water tanks filled with normal tap water, installed with aerator and thermostat. They were kept under natural daylight and darkness (12 L: 12D) and fed with commercial feed pellets at ad libitum. The $\mathrm{pH}$, temperature and dissolved oxygen level of water were recorded to be $7.04 \pm 0.1,25 \pm 1{ }^{\circ} \mathrm{C}$ (control temperature) and $6.2 \mathrm{~mL} / \mathrm{L}$ respectively. Hardness was found to be negligible. The physico-chemical standards of water were maintained according to APHA, AWWA, WPCF (2005).

\section{Critical temperature ( $\mathrm{CT}_{\mathrm{MIN}}$ and $\mathrm{CT}_{\mathrm{MAX}}$ )}

Critical temperature $(\mathrm{CT})$ is the degree at which the locomotor activity of the fish is seized which eventually leads to death called temperature of lethality (LT) (Moyano et al., 2017). The $\mathrm{CT}_{\mathrm{MIN}}$ and $\mathrm{CT}_{\mathrm{MAX}}$ was recorded by increasing and decreasing the temperature of 2 separate tanks by a magnitude of $1^{\circ}$ every $1 \mathrm{~h}$ starting from $25^{\circ} \mathrm{C}$ (control temperature). This was finally found to be $15^{\circ} \mathrm{C}\left(\mathrm{CT}_{\text {MIN }}\right)$ and $35^{\circ} \mathrm{C}\left(\mathrm{CT}_{\text {MAX }}\right)$.

\section{Experimental design}

Fishes were maintained at three different temperature levels for experimentation viz., $15^{\circ} \mathrm{C} \pm 1{ }^{\circ} \mathrm{C}$ (low), $25^{\circ} \mathrm{C}$ $\pm 1{ }^{\circ} \mathrm{C}$ (control) and $35^{\circ} \mathrm{C} \pm 1{ }^{\circ} \mathrm{C}$ (high). Two replicates with 5 fishes in every tank were maintained for each temperature level. The setup was maintained for two time periods viz, 3 and $6 \mathrm{~h}$. At the end of each time slot, the fishes were sacrificed by transferring them into clove oil solution $(1 \mathrm{~mL} / \mathrm{L})$ till complete operculum arrest.

\section{Tissue homogenate preparation}

The gills and dorsal white muscles were carefully dissected and washed in ice-cold buffer solution (phosphate buffer, $0.1 \mathrm{M}, \mathrm{pH}$ 7.4). Tissues were quashed, and $10 \%$ homogenate was made in a glass/Teflon Potter-Elvejhem tissue grinder. The samples were centrifuged at $5000 \times g$ and the supernatants were stored immediately at $-20^{\circ} \mathrm{C}$, until biochemical analyses. All the absorbance values were recorded using visible spectrophotometer (Systronics).

\section{Biochemical analyses \\ Lipid peroxidation assay}

LPO was estimated by the the method of Niehaus and Samuelsson (1968). A mixture of trichloroacetic acid (15\%), thiobarbituric acid (0.38\%) and hydrochloric acid $(0.25 \mathrm{~N})$ was made in equal proportions. A sample of 0.5 $\mathrm{mL}$ was mixed with $1 \mathrm{~mL}$ of the TCA-TBA-HCl reagent. The reaction mixture was heated in a boiling water bath for $15 \mathrm{~min}$, cooled and centrifuged at $1100 \times g$. The absorbance of the supernatant was read at $535 \mathrm{~nm}$ using a spectrophotometer. The rate of peroxidised lipid in each sample was measured as $\mathrm{mM}$ malondialdehyde (MDA) per mg protein.

\section{Catalase}

Catalase activity was measured by the method of Sinha (1972). Briefly, $0.9 \mathrm{~mL}$ of phosphate buffer $(0.01 \mathrm{M}, \mathrm{pH}$ 7.4), $0.4 \mathrm{~mL}$ of $\mathrm{H}_{2} \mathrm{O}_{2}(0.2 \mathrm{M})$ was mixed properly. The reaction was initiated by adding $0.4 \mathrm{~mL}$ of tissue homogenate and after $30 \mathrm{~s}, 2 \mathrm{~mL}$ of the dichromate-acetic acid reagent $(5 \%$ potassium dichromate in glacial acetic 
acid) was added. The reaction mixture was kept for a boiling water bath for $10 \mathrm{~min}$ and then cooled. The absorbance of the colour was read at $610 \mathrm{~nm}$ using a spectrophotometer. Catalase activity was recorded as $\mu$ mole $\mathrm{H}_{2} \mathrm{O}_{2}$ decomposed/min/mg protein.

\section{Glutathione-S-transferase}

GST activity was measured spectrophotometrically at $340 \mathrm{~nm}$ by the protocol of Habig, Pabst, and Jakoby (1974). The reaction mixture contained sample, phosphate buffer (0.1 M; pH 6.5), distilled water and $30 \mathrm{mM}$ of 2,4-Dinitrochlorobenzene (CDNB) amounting to 2.5 $\mathrm{mL}$. The activity was started by the addition of $0.1 \mathrm{M}$ GSH. The activity was expressed as mmoles CDNB conjugated/mg protein.

\section{Glutathione (reduced)}

GSH activity was measured according to the method described by Moron, Depierre, and Mannervik (1979). The reaction mixture consisted of $3 \mathrm{~mL}$ phosphate buffer, $0.1 \mathrm{~mL}$ of the tissue homogenate and $0.5 \mathrm{~mL}$ Ellman's reagent. The solution was read spectrophotometrically at $420 \mathrm{~nm}$ and expressed as $\mathrm{mmol} / \mathrm{mL}$ sample.

\section{Glucose}

Glucose level was assayed according to Nelson and Smogyi (Nelson, 1944; Smogyi, 1952). A $4 \mathrm{~mL}$ of reaction mixture (sample and deproteinizing agent $\mathrm{Ba}(\mathrm{OH})_{2} ; \mathrm{ZnSO}_{4}$ ) was centrifuged at $5000 \times g$ for $10 \mathrm{~min}$. A $1 \mathrm{~mL}$ of this supernatant was added to $1 \mathrm{~mL}$ alkaline copper reagent (potassium-sodium tartrate; $\mathrm{Na}_{2} \mathrm{CO}_{3} ; \mathrm{NaHCO}_{3}$ and $\mathrm{Na}_{2} \mathrm{SO}_{4}$ in distilled water). This mixture was heated in a boiling water bath for $20 \mathrm{~min}$ and cooled after which arseno-molybdate reagent and distilled water was added. The colour developed was read at $540 \mathrm{~nm}$ using a spectrophotometer and the concentration expressed as \% $\mathrm{mg}$ glucose.

\section{Protein}

Protein was estimated according to Lowry, Rosebrough, Farr, and Randall (1951) using bovine serum albumin as standard at $660 \mathrm{~nm}$.

\section{Statistical analyses}

Statistical analysis was carried out using GraphPad Prism 5.0 (GraphPad Inc. CA, USA). Data was represented as mean \pm SE. The mean difference was determined by two-way analysis of variance (ANOVA), followed by Bonferroni post-test. Statistical threshold was fixed at 95\% probability value $(p<0.05)$.

\section{Results}

Lipid peroxidation

In the gills, MDA level ranged from $0.45 \pm 0.04 \mathrm{mM}$ $\mathrm{MDA} / \mathrm{mg}$ protein $\left(15^{\circ} \mathrm{C} ; 3 \mathrm{~h}\right)$ to $4.01 \pm 0.54 \mathrm{mM} \mathrm{MDA} /$ mg protein $\left(35^{\circ} \mathrm{C} ; 6 \mathrm{~h}\right)$ (Fig. 1a). In the muscles, the level ranged from $0.57 \pm 0.10\left(15^{\circ} \mathrm{C} ; 3 \mathrm{~h}\right)$ to $1.81 \pm 0.14 \mathrm{mM}$ MDA/mg protein $\left(15^{\circ} \mathrm{C} ; 6 \mathrm{~h}\right)$ (Fig. 1b). Compared with the control, the levels of MDA were low in both the tissues, throughout the study. Temperature exerted a greater effect than time for LPO levels on the gills, while, time as an individual entity did not have any significant impact on the muscles (Table 1).

\section{Catalase}

The catalase activity ranged from $3.66 \pm 0.52\left(15^{\circ} \mathrm{C} ; 3 \mathrm{~h}\right)$ to $8.825 \pm 0.34 \mu$ mole $\mathrm{H}_{2} \mathrm{O}_{2}$ decomposed $/ \mathrm{min} / \mathrm{mg}$ protein $\left(35^{\circ} \mathrm{C} ; 3 \mathrm{~h}\right)$ in gills (Fig. 2a). This was higher compared with the muscles that ranged from $2.65 \pm 0.23$ $\left(15^{\circ} \mathrm{C} ; 3 \mathrm{~h}\right)$ to $4.32 \pm 0.62 \mu$ mole $\mathrm{H}_{2} \mathrm{O}_{2}$ decomposed $/ \mathrm{min} /$ mg protein $\left(35^{\circ} \mathrm{C} ; 3 \mathrm{~h}\right)$ (Fig. $\left.2 \mathrm{~b}\right)$. Both tissues reported the maximum catalase activity at $35^{\circ} \mathrm{C}(3 \mathrm{~h}$ period) $(8.82 \pm$ 0.69 (gills) and $4.32 \pm 1.24$ (muscles)). Further, the catalase activity in the gills was elevated throughout the study at all temperatures as opposed to the muscles, when compared with the controls (Table 1).

\section{Glutathione S-transferase}

The GST activity ranged from $0.33 \pm 0.01$ mmoles $\mathrm{CDNB}$ conjugated $/ \mathrm{mg}$ protein $\left(35^{\circ} \mathrm{C} ; 6 \mathrm{~h}\right)$ to $12.68 \pm$ $0.54 \mathrm{mmoles} \mathrm{CDNB}$ conjugated $/ \mathrm{mg}$ protein $\left(35^{\circ} \mathrm{C} ; 3 \mathrm{~h}\right)$ for the gills (Fig. 3a). In the muscles, it was from $0.34 \pm$ $0.01 \mathrm{mmoles} C \mathrm{CDNB}$ conjugated/mg protein $\left(15^{\circ} \mathrm{C} ; 6 \mathrm{~h}\right)$ to $14.25 \pm 0.06 \mathrm{mmoles} \mathrm{CDNB}$ conjugated $/ \mathrm{mg}$ protein $\left(35^{\circ} \mathrm{C} ; 3 \mathrm{~h}\right)$ (Fig. $\left.3 \mathrm{~b}\right)$. A significant spike in the GST activity was noted at $35^{\circ} \mathrm{C}(3 \mathrm{~h})$ which recorded $12.68 \pm$ $0.54 \mathrm{mmoles}$ CDNB conjugated $/ \mathrm{mg}$ protein for the gills and $14.25 \pm 0.06 \mathrm{mmoles}$ CDNB conjugated $/ \mathrm{mg}$ protein for the muscles (Table 1).

\section{Glutathione reduced}

GSH level was elevated throughout the study in both the tissues at all the experimental temperature-time levels, compared with the control. The value in the gills ranged from $3.14 \pm 0.54 \mathrm{mmol} / \mathrm{mL}$ sample $\left(35^{\circ} \mathrm{C}\right.$; $3 \mathrm{~h}$ to $12.89 \pm$ $0.40 \mathrm{mmol} / \mathrm{mL}$ sample $\left(15^{\circ} \mathrm{C} ; 3 \mathrm{~h}\right.$ ) (Fig. $\left.4 \mathrm{a}\right)$. In the muscles, it ranged from $2.21 \pm 0.26 \mathrm{mmol} / \mathrm{mL}$ sample $\left(35^{\circ} \mathrm{C}\right.$; $6 \mathrm{~h})$ to $5.78 \pm 0.13 \mathrm{mmol} / \mathrm{mL}$ sample $\left(35^{\circ} \mathrm{C} ; 3 \mathrm{~h}\right.$ ) (Fig. $4 \mathrm{~b}$ ). Significant differences were observed in the experimental temperature regimes when compared to the controls for both 3 and 6 h (Table 1).

\section{Glucose}

Barring $15^{\circ} \mathrm{C}$, the gills reported a nearly half fold glucose level when compared with the $25^{\circ} \mathrm{C}$ (control group). The highest value for glucose was found at $15^{\circ} \mathrm{C}$ for the 3-h regime for both the tissues $(610 \pm 170.9 \% \mathrm{mg}$ glucose (gills) and $830 \pm 132.2 \% \mathrm{mg}$ glucose (muscles)) (Fig. 5a). While in the muscles, the range was observed as $199 \pm 1.43 \% \mathrm{mg}$ 


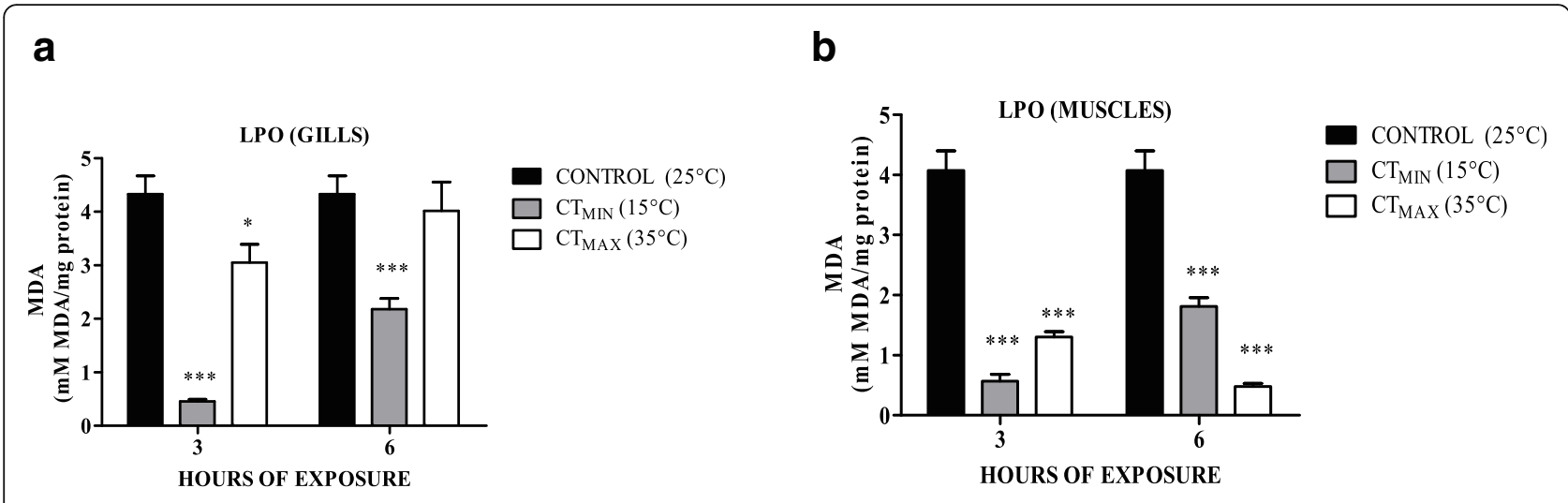

Fig. 1 Effect of temperature on the activity of MDA in the gills (a) and muscles (b) of Koi carps. Significance was calculated by two-way ANOVA followed by Bonferroni post-test where $p<0.001\left(^{* * *}\right) ; p<0.05\left(^{*}\right)$. The vertical lines indicate mean \pm SE. Bars represent different periods of exposure

glucose $\left(35^{\circ} \mathrm{C} ; 6 \mathrm{~h}\right)$ to $830 \pm 66.08 \% \mathrm{mg}$ glucose $\left(15^{\circ} \mathrm{C} ; 3 \mathrm{~h}\right)$ (Fig. 5b). Time had more significant effects (44.89\%) rather than the temperature for the glucose activity in the muscles (Table 1). However, in the case of the gills, the temperature had a greater $(47.90 \%)$ impact on the tissue (Table 1 ).

\section{Behavioural observations}

We observed signs of body fatigue prompted by the exposed temperature levels. The swerved swimming pattern was mainly noted at $35^{\circ} \mathrm{C}$, while at $15^{\circ} \mathrm{C}$, they became lazy and spent time majorly at the bottom of the tank. Laziness, slow secretion of mucous, change in the coloration of the gills as well as body and shedding of scales were majorly observed at both the temperature levels.

\section{Discussion}

The present study focuses on the sustainability of the Koi carps in domesticated environments at two experimental

Table 1 Significance levels of the two-way ANOVA testing effects of temperature (temp: $15^{\circ} \mathrm{C}, 25^{\circ} \mathrm{C}$ and $35^{\circ} \mathrm{C}$ ) and time (time: 3 and $6 \mathrm{~h}$ ) on organs (gills and muscles) of Cyprinus carpio var koi for MDA, catalase, GST, GSH and glucose

\begin{tabular}{|c|c|c|c|c|c|c|c|c|}
\hline Enzyme & Tissue & $\begin{array}{l}\text { Source of } \\
\text { variation }\end{array}$ & $\begin{array}{l}\text { Interaction(\%) } \\
\text { (temp vs time) }\end{array}$ & $d f$ & SS & MSQ & $F$ & $P$ value \\
\hline \multirow[t]{4}{*}{ MDA } & Gill & Temp & 70.79 & 2 & 38.89 & 19.45 & 42.48 & $<0.0001$ \\
\hline & & Time & 8.76 & 1 & 4.815 & 4.815 & 10.52 & 0.0045 \\
\hline & Muscle & Temp & 86.8 & 2 & 49.43 & 24.71 & 145.2 & $<0.0001$ \\
\hline & & Time & 0.21 & 1 & 0.119 & 0.119 & 0.699 & 0.4141 \\
\hline \multirow[t]{4}{*}{ Catalase } & Gill & Temp & 85.2 & 2 & 113.4 & 56.72 & 73.13 & $<0.0001$ \\
\hline & & Time & 0.23 & 1 & 0.3038 & 0.3038 & 0.3916 & 0.5393 \\
\hline & Muscle & Temp & 61.82 & 2 & 20.66 & 10.33 & 22.14 & $<0.0001$ \\
\hline & & Time & 0.74 & 1 & 0.246 & 0.246 & 0.5272 & 0.4771 \\
\hline \multirow[t]{4}{*}{ GST } & Gill & Temp & 32.13 & 2 & 146.4 & 73.18 & 284 & $<0.0001$ \\
\hline & & Time & 22.62 & 1 & 103 & 103 & 399.9 & $<0.0001$ \\
\hline & Muscle & Temp & 36.89 & 2 & 224.8 & 112.4 & 9356 & $<0.0001$ \\
\hline & & Time & 21.14 & 1 & 128.9 & 128.9 & 10720 & $<0.0001$ \\
\hline \multirow[t]{4}{*}{ GSH } & Gill & Temp & 84.46 & 2 & 294.7 & 147.4 & 364.8 & $<0.0001$ \\
\hline & & Time & 2.5 & 1 & 8.712 & 8.712 & 21.57 & 0.0002 \\
\hline & Muscle & Temp & 37.51 & 2 & 18.15 & 9.073 & 38.61 & $<0.0001$ \\
\hline & & Time & 13.48 & 1 & 6.521 & 6.521 & 27.75 & $<0.0001$ \\
\hline \multirow[t]{4}{*}{ Glucose } & Gill & Temp & 47.9 & 2 & 305800 & 152900 & 26.68 & $<0.0001$ \\
\hline & & Time & 11.06 & 1 & 70630 & 70630 & 12.32 & 0.0025 \\
\hline & Muscle & Temp & 8.3 & 2 & 112800 & 56390 & 4.169 & 0.0325 \\
\hline & & Time & 44.89 & 1 & 609600 & 609600 & 45.07 & $<0.0001$ \\
\hline
\end{tabular}




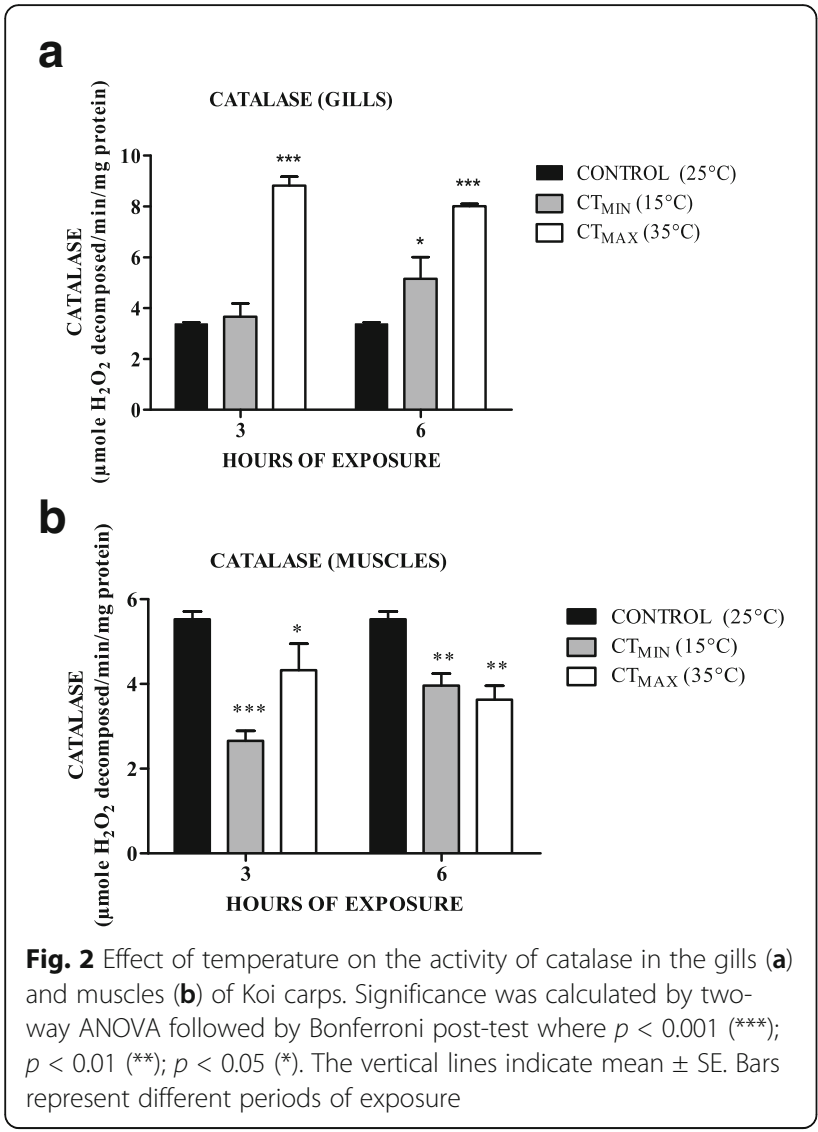

sub-lethal temperatures amounting to short-term stress. For any aquatic organism, the temperature has closely been associated with several metabolic processes such as oxygen consumption (Das et al., 2005; Koopman, Collas, van der Velde, \& Verberk, 2016), biochemical composition, growth and reproduction (Tropea, Stumpf, \& López Greco, 2015) and behaviour (Padilla-Ramírez et al., 2015).

The present study shows a significant impact of temperature on the MDA levels of the gills and muscles, which was dependent on the source of variation between time and temperature. An increasing trend for MDA was observed in our study initiating from $15^{\circ} \mathrm{C}$ to $35^{\circ} \mathrm{C}$, likewise, reported in Dicentrarchus labrax (Vinagre, Madeira, Narciso, Cabral, \& Diniz, 2012) and Sparus aurata (Madeira, Madeira, et al., 2016a). Perhaps, the temperature gradient is proportional to the level of MDA, which has also been reported in Heteropneustes fossilis by Parihar and Dubey (1995). Generally, as the time increases, high temperatures disrupt the lipid stability and therefore decomposition of the fatty acids might produce free radicals (Joy et al., 2017). Hence, we believe that the increase in the temperature at the short duration has the same analogy as that of longer duration.

Akhtar, Pal, Sahu, Ciji, and Mahanta (2013) and Vinagre et al. (2012) have accounted for the activity of catalase as an antioxidant enzyme and its modulation under a

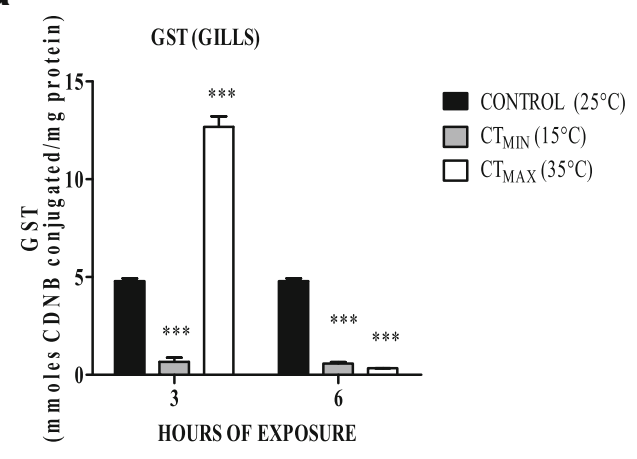

b

要

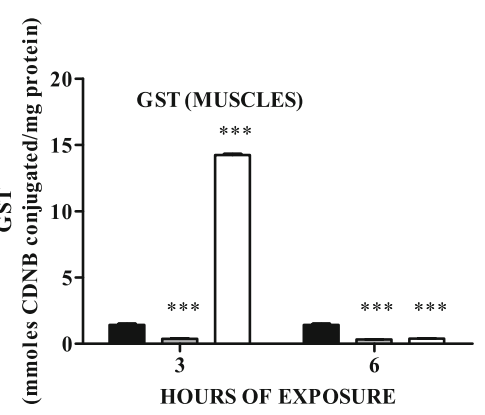

Fig. 3 Effect of temperature on the activity of GST in the gills (a) and muscles (b) of Koi carps. Significance was calculated by twoway ANOVA followed by Bonferroni post-test where $p<0.001$ (**). $^{* *}$.

The vertical lines indicate mean \pm SE. Bars represent different periods of exposure

temperature stress. Our results showed an increasing trend of catalase activity in the gills for 3- and 6-hour exposure period $\left(15^{\circ} \mathrm{C}\right.$ and $\left.35^{\circ} \mathrm{C}\right)$ as compared with the muscle $(6 \mathrm{~h})$, indicating that the temperature stress has induced a more stubborn defence in the gills than the muscles. Such a trend was also observed in Paralichthys orbignyanus from a transition of $23^{\circ} \mathrm{C}$ to $28.8^{\circ} \mathrm{C}$ (Garcia et al., 2015). In our study, catalase antioxidant activity outweighed the LPO levels of the muscles at both the experimental temperature-time levels indicating the surprising capacity of the fish to overcome stress in a short period.

Leggatt, Brauner, Schulte, and Iwama (2007) and Bagnyukova, Lushchak, Storey, and Lushchak (2007) have reported the importance of glutathione family and their coordinated responses to counteract oxidative stress. The present study demonstrated higher GSH level than that of control temperature for both the thermal levels and tissues. Nakano et al. (2014), also reported the elevated GSH levels in the liver of Oncorhynchus kisutch. The initial 3-h exposure $\left(15^{\circ} \mathrm{C}\right.$ and $\left.35^{\circ} \mathrm{C}\right)$ recorded a consistent increase in the GSH levels of the muscles, therefore, leading to a significant impact of both temperature and time, on the expression of GSH levels. This was similar in case of two species analysis of Notothenia (Notothenia coriiceps and Notothenia rossii) (Machado et al., 2014). 


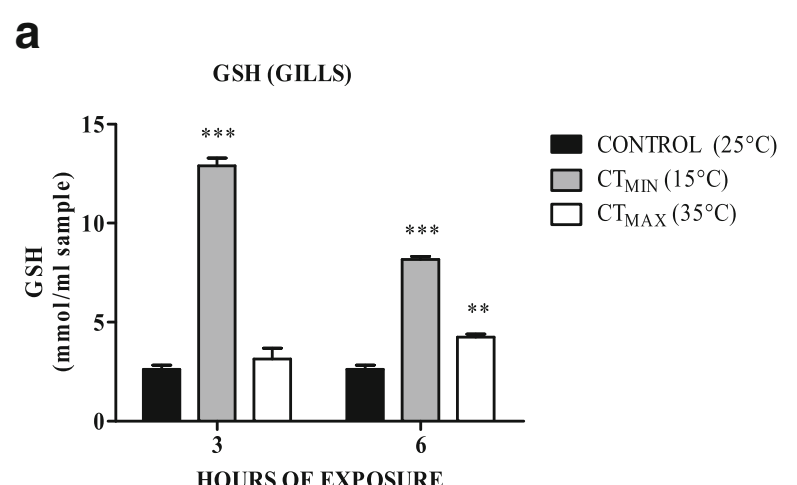

b

Fig. 4 Effect of temperature on the activity of GSH in the gills (a) and muscles (b) of Koi carps. Significance was calculated by two-way ANOVA followed by Bonferroni post-test where $p<0.001\left(^{(* *)}\right) ; p<0.01\left(^{* *}\right)$. The vertical lines indicate mean \pm SE. Bars represent different periods of exposure

Glutathione metabolism is affected by various temperature fluctuations irrespective of the time (Lushchak \& Bagnyukova, 2006; Nakano et al., 2014). Initially, for a 3-h duration $\left(35^{\circ} \mathrm{C}\right)$, both the tissues reported GST increase along with the temperature. However, contrary to our expectations, the level reduced drastically as the duration proceeded to $6 \mathrm{~h}$ for $35^{\circ} \mathrm{C}$. Rossi, Bacchetta, and Cazenave (2017) have observed a similar shift in the gills of Hoplosternum littorale from $10^{\circ} \mathrm{C}$ to $33^{\circ} \mathrm{C}$. It might be considered that antioxidant enzyme responses might depend upon the conditions, the organism is exposed towards. For example, Madeira, Narciso, Cabral, Vinagre, and Diniz (2013) reported a species-specific experimental analysis of temperature affected GST in Diplodus vulgaris and found that its proliferation is facilitated as the $\mathrm{CT}_{\text {MAX }}$ is approached.

Glucose is majorly involved in necessity-based transformation of chemical to mechanical energy. Being a primary energy molecule, it is extremely sensitive to varying levels of stress and its regulation is done according to the feedback mechanism (Jiang, Wu, Huang, Ren, \& Wang, 2017). Wells and Pankhurst (1999) have also reported a positive correlation of stress with glucose. We observed an initial elevation of glucose in the gills and muscles at $15{ }^{\circ} \mathrm{C}$ (3-h and 6-h exposure), which further reduced as the temperature was raised. A similar condition has been studied in Sebastes mystinus at $5{ }^{\circ} \mathrm{C}$, which suggested a reduced need for ATP and its associated metabolites and metabolism at low temperature, concluding with an evident reduction in glycolysis. In S. mystinus and $S$. serranoides, it was observed that low-temperature adaptations were useful in orienting glucose to hexose monophosphate (HMP) shunt (Helly Jr., 1976).

\section{Conclusion}

Our study attempts to draw an inference between glucose content and antioxidative profiling in the gills and muscles. We noted a fluctuation in the enzyme levels with the influence of thermal stress on the gills and muscles of Koi carps, in relation to the tolerance capacities. However, the work might vary upon the laboratory conditions and the consequences of these fluctuations might be dictated by such experimental conditions. Our work corroborates the fact that an abiotic factor like

\section{a}

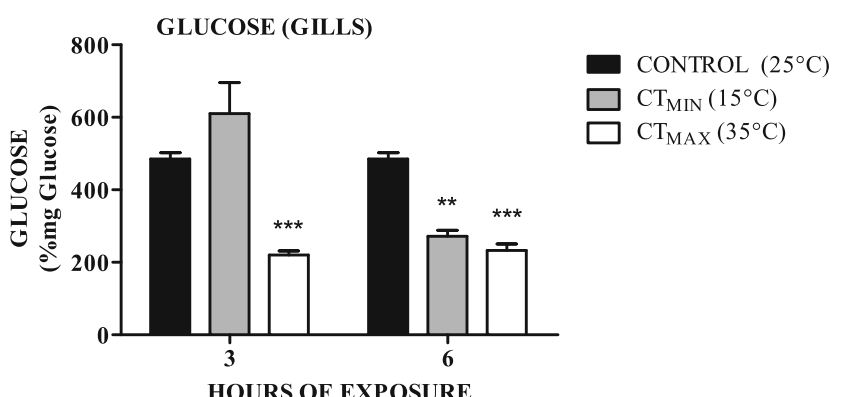

b

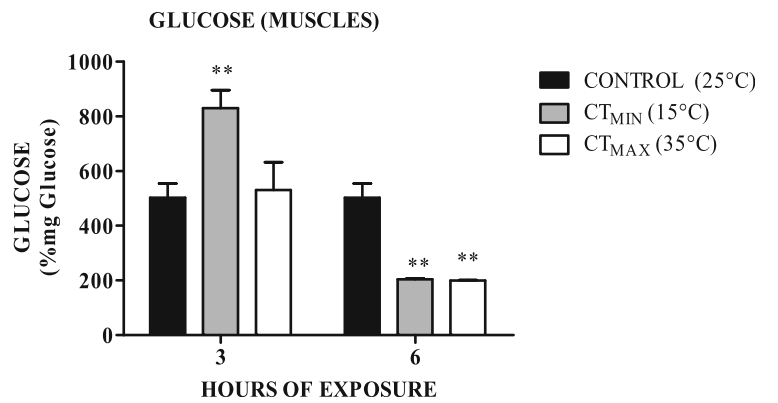

Fig. 5 Effect of temperature on the activity of Glucose in the gills (a) and muscles (b) of Koi carps. Significance was calculated by two-way ANOVA followed by Bonferroni post-test where $p<0.001\left(^{* * *}\right) ; p<0.01\left(^{* *}\right)$. The vertical lines indicate mean \pm SE. Bars represent different periods of exposure 
temperature has a great calibre to disrupt the metabolism and the energy disbursement system of the fish even in a domesticated environment as that of an aquarium. Owing to the commercial aspects, one cannot deny the importance of sustainable propagation of these fishes in the aquaculture industry. Since the rearing and caring of any aquatic organism are dependent on the abiotic factors as they are always in direct contact with water, the temperature is a major contributor to their life span in the domesticated environments.

\section{Acknowledgements}

The authors would like to thank the Department of Zoology, Bangalore University, Bengaluru for providing the necessary technical support during the conduct of present research work.

\section{Authors' contributions}

PD designed the research idea, over-all work and wrote the manuscript. AS helped with the experimental protocols. PD and AS worked on calculations and statistical analysis. BZ revised the drafted manuscript and made necessary corrections. All authors read and approved the final manuscript.

\section{Funding}

This research did not receive any specific grant from funding agencies in the public, commercial, or not-for-profit sectors.

\section{Availability of data and materials}

Not applicable.

\section{Ethics approval and consent to participate}

Indian researchers do not require ethical approval for research on fishes unless they belong to subclass Elasmobranchii (Rays and Sharks) (University Grants Commission (UGC) (Letter-No. F. 14-6/2014 (CPP-II) (https://www.ugc. ac.in/pdfnews/6819407_ugcletterzoology.pdf). Moreover, the present study was carried out in compliance with institutional and national guidelines for handling the experimental animals.

\section{Consent for publication}

Not applicable

\section{Competing interests}

The authors declare that they have no competing interests.

Received: 24 August 2019 Accepted: 28 January 2020

Published online: 07 February 2020

\section{References}

Abele, A., \& Puntarulo, S. (2004). Formation of reactive species and induction of antioxidant defence systems in polar and temperate marine invertebrates and fish. Comparative Biochemistry and Physiology, Part A, 138, 405-415. https://doi.org/10.1016/j.cbpb.2004.05.013.

Akhtar, M. S., Pal, A. K., Sahu, N. P., Ciji, A., \& Mahanta, P. C. (2013). Therma tolerance, oxygen consumption and haemato-biochemical variables of Tor putitora juveniles acclimated to five temperatures. Fish Physiology and Biochemistry, 39, 1387-1398. https://doi.org/10.1007/s10695-013-9793-7.

Allan, B. J. M., Paolo, D., Munday, P. L., \& McCormick, M. I. (2015). Feeling the heat: the effect of acute temperature changes on predator-prey interactions in coral reef fish. Conservation Physiology, 3, 1-8. https://doi.org/10.1093/ conphys/cov011.

APHA, AWWA, WPCF (2005). Standard methods for the examination of water and waste water 21st, (401st ed., ). Washington, DC: American Public Health Association.

Bagnyukova, T. V., Lushchak, O. V., Storey, K. B., \& Lushchak, V. I. (2007). Oxidative stress and antioxidant defense responses by goldfish tissues to acute change of temperature from 3 to $23^{\circ} \mathrm{C}$. Journal of Thermal Biology, 32, 227-234. https://doi.org/10.1016/j.jtherbio.2007.01.004.

Campos, D. F., Val, A. L., \& Almeida-Val, V. M. F. (2018). The influence of lifestyle and swimming behavior on metabolic rate and thermal tolerance of twelve
Amazon forest stream fish species. Journal of Thermal Biology, 72, 148-154. https://doi.org/10.1016/j.jtherbio.2018.02.002

Das, T., Pal, A. K., Chakraborty, S. K., Manush, S. M., Sahu, N. P., \& Mukherjee, S. C. (2005). Thermal tolerance, growth and oxygen consumption of Labeo rohita fry (Hamilton, 1822) acclimated to four temperatures. Journal of Thermal Biology, 30, 378-383. https://doi.org/10.1016/j.jtherbio.2005.03.001.

Di Giulio, R. T., Washburn, P. C., Wenning, R. J., Winston, G. W., \& Jewell, C. S. (1989). Biochemical responses in aquatic animals: a review of determinants of oxidative stress. Environmental Toxicology und Chemistry, 8, 1103-1123. https://doi.org/10.1002/etc.5620081203.

Dong, Y., Dong, S., \& Ji, T. (2008). Effect of different thermal regimes on growth and physiological performance of the sea cucumber Apostichopus japonicus Selenka. Aquaculture, 275, 329-334. https://doi.org/10.1016/j.aquaculture.2007. 12.006

Freitas, R., DeMarchi, L., Bastos, M., Moreira, A., Velez, C., Chiesa, S., ... Soares, M. V. M. A. (2017). Effects of seawater acidification and salinity alterations on metabolic, osmoregulation and oxidative stress markers in Mytilus galloprovincialis. Ecological Indicators, 79, 54-62. https://doi.org/10.1016/j. ecolind.2017.04.003.

Garcia, L., De, O., Okamoto, H. M., Riffel, A. P. K., Saccol, M. E., Pavanato, M. A., \& Sampaio, L. A. N. (2015). Oxidative stress parameters in juvenile Brazilian flounder Paralichthys orbignyanus (Valenciennes, 1839) (Pleuronectiformes: Paralichthyidae) exposed to cold and heat shocks. Neotropical Ichthyology, 13(3), 607-612. https://doi.org/10.1590/1982-0224-20140148.

Gutteridge, J. M. (1995). Lipid peroxidation and antioxidants as biomarkers of tissue damage. Clinical Chemistry, 41(12 Pt 2), 1819-1828.

Habig, W. H., Pabst, M. J., \& Jakoby, W. B. (1974). Glutathione S-transferases. The first enzymatic step in mercapturic acid formation. The Journal of Biological Chemistry, 249(22), 7130-7139.

Helly Jr., J. J. (1976). The effect of temperature and thermal distribution on glycolysis in two rockfish species (Sebastes). Marine Biology, 37(1), 89-95.

Hsu, C. Y., \& Chiu, C. Y. (2009). Ambient temperature influences aging in an annual fish (Nothobranchius rachovii). Aging Cell, 8, 726-737. https://doi.org/ 10.1111/j.1474-9726.2009.00525.x.

Jiang, D., Wu, Y., Huang, D., Ren, X., \& Wang, Y. (2017). Effect of blood glucose level on acute stress response of grass carp Ctenopharyngodon idella. Fish Physiology and Biochemistry, 43(5), 1433-1442. https://doi.org/10.1007/s10695017-0383-y.

Joy, S., Alikunju, P. A., Jose, J., Sudha, H. S. H., Parambath, M. P., Puthiyedathu, T. S. \& Philip, B. (2017). Oxidative stress and antioxidant defense responses of Etroplus suratensis to acute temperature fluctuations. Journal of Thermal Biology, 70, 20-26. https://doi.org/10.1016/j.jtherbio.2017.10.010.

Kaur, M., Atif, F., Ali, M., Rehman, H., \& Raisuddin, S. (2005). Heat stress-induced alterations of antioxidants in the freshwater fish Channa punctata Bloch. Journal of Fish Biology, 67, 1653-1665. https://doi.org/10.1111/j.1095-8649. 2005.00872.x

Koopman, K. R., Collas, F. P. L., van der Velde, G., \& Verberk, W. C. E. P. (2016). Oxygen can limit heat tolerance in freshwater gastropods: differences between gill and lung breathers. Hydrobiologia, 763(1), 301-312. https://doi. org/10.1007/s10750-015-2386-y.

Kumar, N., Krishnani, K. K., \& Singh, P. N. (2018). Effect of dietary zinc-nanoparticles on growth performance, anti-oxidative and immunological status of fish reared under multiple stressors. Biological Trace Element Research, 186(1), 267-278. https://doi.org/10.1007/s12011-018-1285-2.

Leggatt, R. A., Brauner, C. J., Schulte, P. M., \& Iwama, G. K. (2007). Effects of acclimation and incubation temperature on the glutathione antioxidant system in killifish and RTH-149 cells. Comparative Biochemistry \& Physiology, 146A, 317-326. https://doi.org/10.1016/j.cbpa.2006.10.033.

Lowry, O. H., Rosebrough, N. J., Farr, A. L., \& Randall, R. J. (1951). Protein measurement with the Folin phenol reagent. The Journal of Biological Chemistry, 193(1), 265-275.

Lushchak, V. I. (2011). Environmentally induced oxidative stress in aquatic animals. Aquatic Toxicology, 101(1), 13-30. https://doi.org/10.1016/j. aquatox.2010.10.006.

Lushchak, V. I. (2016). Contaminant-induced oxidative stress in fish: a mechanistic approach. Fish Physiology and Biochemistry, 42, 711-747. https://doi.org/10. 1007/s10695-015-0171-5.

Lushchak, V. I., \& Bagnyukova, T. V. (2006). Temperature increase results in oxidative stress in goldfish tissues. 2. Antioxidant and associated enzymes. Comparative Biochemistry and Physiology Part C, 143(1), 36-41. https://doi.org/ 10.1016/j.cbpc.2005.11.018. 
Mabuchi, K., Seno, H., Suzuki, T., \& Nishida, M. (2005). Discovery of an ancient lineage of Cyprinus carpio from Lake Biwa, central Japan, based on mtDNA sequence data, with reference to possible multiple origins of koi. Journal of Fish Biology, 66, 1516-1528. https://doi.org/10.1111/j.1095-8649.2005.00676.x.

Machado, C., Zaleski, T., Rodrigues, E., Carvalho, C. S., Cadena, S. M., Gozzi, G. J., ... Donatti, L. (2014). Effect of temperature acclimation on the liver antioxidant defence system of the Antarctic notothenioids Notothenia coriiceps and Notothenia rossii. Comparative Biochemistry and Physiology, Part B, 172-173, 21-28. https://doi.org/10.1016/j.cbpb.2014.02.003.

Madeira, D., Vinagre, C., \& Diniz, M. S. (2016a). Are fish in hot water? Effects of warming on oxidative stress metabolism in the commercial species Sparus aurata. Ecological Indicators, 63, 324-331. https://doi.org/10.1016/j.ecolind.2015.12.008.

Madeira, D., Narciso, L., Cabral, H. N., Vinagre, C., \& Diniz, M. S. (2013). Influence of temperature in thermal and oxidative stress responses in estuarine fish. Comparative Biochemistry and Physiology—A Molecular and Integrative Physiology, 166, 237-243. https://doi.org/10.1016/j.cbpa.2013.06.008.

Madeira, C., Madeira, D., Diniz, M. S., Cabral, H. N., \& Vinagre, C. (2016b). Thermal acclimation in clownfish: an integrated biomarker response and multi-tissue experimental approach. Ecological Indicators, 71, 280-292. https://doi.org/10 1016/j.ecolind.2016.07.009

Moron, M. S., Depierre, J. W., \& Mannervik, M. (1979). Levels of glutathione, glutathione reductase and glutathione S-transferase activities in rat lung and liver. Biochimica et Biophysica Acta (BBA) - General Subjects, 582(1), 67-78. https://doi.org/10.1016/0304-4165(79)90289-7.

Moyano, M., Candebat, C., Ruhbaum, Y., Álvarez-Fernández, S., Claireaux, G., Zambonino-Infante, J. L., \& Peck, M. A. (2017). Effects of warming rate, acclimation temperature and ontogeny on the critical thermal maximum of temperate marine fish larvae. PLOS ONE, 12(7), e0179928. https://doi.org/10. 1371/journal.pone.0179928.

Nakano, T., Kameda, M., Shoji, Y., Hayashi, S., Yamaguchi, T., \& Sato, M. (2014). Effect of severe environmental thermal stress on redox state in salmon. Redox Biology, 2, 772-776. https://doi.org/10.1016/j.redox.2014.05.007.

Nelson, N. (1944). A photometric adaptation of the somogyi method for determination of glucose. Journal of Biological Chemistry, 153, 375-380.

Niehaus, W. G.s \& Samuelsson, B. (1968). Formation of malonaldehyde from phospholipid arachidonate during microsomal lipid peroxidation. European Journal of Biochemistry, 6(1), 126-130. https:/doi.org/10.1111/j.1432-1033.1968.tb00428x.

Padilla-Ramírez, S., Díaz, F., Re, A. D., Galindo-Sanchez, C. E., Sanchez-Lizarraga, A. L., Nuñez-Moreno, L. A., ... Rosas, C. (2015). The effects of thermal acclimation on the behavior, thermal tolerance, and respiratory metabolism in a crab inhabiting a wide range of thermal habitats (Cancer antennarius Stimpson, 1856, the red shore crab). Marine and Freshwater Behaviour and Physiology, 48, 89-101. https://doi.org/10.1080/10236244.2015.1019212.

Parihar, M. S., \& Dubey, A. K. (1995). Lipid peroxidation and ascorbic acid status in respiratory organs of male and female freshwater catfish Heteropneustes fossilis exposed to temperature increase. Comparative Biochemistry \& Physiology, 112(3), 309-313. https://doi.org/10.1016/0742-8413(95)02025-X.

Rossi, A., Bacchetta, C., \& Cazenave, J. (2017). Effect of thermal stress on metabolic and oxidative stress biomarkers of Hoplosternum littorale (Teleostei, Callichthyidae). Ecological Indicators, 79, 361-370. https://doi.org/10.1016/.ecolind.2017.04.042.

Sinha, A. K. (1972). Colorimetric assay of catalase. Analytical Biochemistry, 47, 389-394.

Smogyi, M. (1952). Notes on sugar determination. Journal of Biological Chemistry, 195(1), 19-23.

Tripathi, N. K., Latimer, K. S., Lewis, T., \& Burnley, V. V. (2003). Biochemical reference intervals for koi (Cyprinus carpio). Comparative Clinical Pathology, 12, 160-165. https://doi.org/10.1007/s00580-003-0495-x.

Tropea, C., Stumpf, L., \& López Greco, L. S. (2015). Effect of temperature on biochemical composition, growth and reproduction of the ornamental red cherry shrimp Neocaridina heteropoda heteropoda (Decapoda, Caridea). PLoS ONE, 10(3), e0119468. https://doi.org/10.1371/journal.pone.0119468.

Vinagre, C., Madeira, D., Narciso, L., Cabral, H., \& Diniz, M. (2012). Effect of temperature on oxidative stress in fish: lipid peroxidation and catalase activity in the muscle of juvenile seabass, Dicentrarchus labrax. Ecological Indicators, 23, 274-279. https://doi.org/10.1016/j.ecolind.2012.04.009.

Wells, R. M. G., \& Pankhurst, W. N. (1999). Evaluation of simple instruments for the measurement of blood glucose and lactate, and plasma protein as stress indicators in fish. Journal of The World Aquaculture Society, 30(2), 276-284

\section{Publisher's Note}

Springer Nature remains neutral with regard to jurisdictional claims in published maps and institutional affiliations.

\section{Submit your manuscript to a SpringerOpen ${ }^{\circ}$ journal and benefit from:}

- Convenient online submission

- Rigorous peer review

- Open access: articles freely available online

- High visibility within the field

- Retaining the copyright to your article

Submit your next manuscript at $\boldsymbol{\nabla}$ springeropen.com 